\title{
Symptoms, Distribution and Abundance of the Stem-Boring Caterpillar, Blastobasis repartella (Dietz), in Switchgrass
}

\author{
Jarrad R. Prasifka $\cdot$ Jeffrey D. Bradshaw $\cdot$ \\ Arvid A. Boe • DoKyoung Lee • David Adamski • \\ Michael E. Gray
}

Published online: 10 December 2009

(C) The Author(s) 2009. This article is published with open access at Springerlink.com

\begin{abstract}
A potential pest of switchgrass, Panicum virgatum L., was first detected in South Dakota in 2004, where death of partially emerged leaves was noted in a small proportion of tillers. Similar "dead heart" symptoms were observed in switchgrass in Illinois during 2008 and adults of a stem-boring caterpillar were collected and identified as Blastobasis repartella (Dietz). In 2009, a survey of the central United States was used to estimate the distribution and abundance of this insect. In eight northern states, $B$. repartella was consistently found in both cultivated plots and natural stands of switchgrass. In four southern states, $B$. repartella was not detected. However, because symptoms are conspicuous for a short period of time, failure to collect stem-borers on one survey date for each southern location does not necessarily define the limit of distribution for $B$. repartella. Sampling in four northern states showed the proportion of tillers damaged by B. repartella ranged from
\end{abstract}

J. R. Prasifka · J. D. Bradshaw

Energy Biosciences Institute, University of Illinois,

Urbana, IL, USA

A. A. Boe

Plant Science Department, South Dakota State University, Brookings, SD, USA

D. K. Lee $\cdot$ M. E. Gray

Department of Crop Sciences, University of Illinois,

Urbana, IL, USA

D. Adamski

Department of Entomology, Smithsonian Institution,

Washington, DC, USA

\section{J. R. Prasifka $(\bowtie)$}

Energy Biosciences Institute, Institute for Genomic Biology,

Room 1117, University of Illinois,

Urbana, IL 61801, USA

e-mail: prasifka@illinois.edu
1.0-7.2\%. Unlike some caterpillars that feed on native grasses, it appears that the egg-laying behavior of adult moths may preclude the use of prescribed burns as an effective method to suppress this stem-boring caterpillar. As a potential pest of switchgrass planted for biomass production, near-term research needs include refining the geographic distribution of $B$. repartella, quantifying potential losses of switchgrass biomass, and determining whether switchgrass may be bred for resistance this and other stemboring insects.

Keywords Biofuel $\cdot$ Coleophoridae $\cdot$ Microlepidoptera . Tallgrass prairie $\cdot$ Yield

\section{Introduction}

Perennial rhizomatous grasses, including switchgrass, Panicum virgatum L., are considered low-input crops for biomass production, in part because they should require little to no management for insect pests $[11,12]$. However, observations of feeding by several orders of herbivorous insects suggest that rather than being pest-free, the identity of insect pests and their effects on harvestable biomass are simply not yet known $[4,8]$. One potential pest was first detected near Pierre, South Dakota in May 2004, where death of partially emerged leaves was a conspicuous symptom in a small proportion of tillers of 'Dacotah' and 'Cave-In-Rock' switchgrass. Since some healthy lower leaves were present, damage to leaves was initially attributed to a late freeze. However, subsequent examination revealed caterpillars tunneling within the damaged tillers, and the insect was reported as an unidentified stemborer [10]. Feeding by the caterpillars resulted in cessation of growth, preventing accumulation of additional biomass 
for infested tillers. Similarly, other stalk-boring caterpillars in maize, sorghum, rice and sugarcane produce conspicuous death of whorl leaves, a symptom often colloquially referred to as "dead heart" [5].

The death of emerging leaves and presence of holes in tillers just above soil level also suggested the presence of a stem-boring insect in 'Cave-In-Rock' switchgrass in Illinois during 2008. However, symptomatic tillers in Illinois contained only rotting tissue and larvae of insects that secondarily invade damaged and decaying plant tissues. After finding that the caterpillars in South Dakota are often collected inside the stem but below soil level, it was concluded that initial attempts to collect larvae in Illinois had been either too shallow or too late in the season. Accordingly, to catch adults of any insects responsible for the damage to 'Cave-In-Rock' tillers, small cages were placed over symptomatic tillers with the metal edges of each cage buried just below soil level. A small number of moths were collected from cages in Illinois and by collection in nets at night, allowing specimens to be submitted for identification.

Because few adults were available, the moths were tentatively identified as Blastobasis repartella Dietz (Lepidoptera: Coleophoridae), a species previously known only from two male specimens collected from Colorado in 1910 [7]. However, specimens from Illinois also closely resembled Blastobasis graminea, which has been described as a pest boring into stems of sugarcane, Saccharum spp. [1, 2], and smooth cordgrass, Spartina alterniflora Loisel [13]. Based on the ability of the stem-boring larvae to stop the growth of infested tillers, efforts in 2009 focused on conducting a survey to better determine the distribution of the Blastobasis species and sampling to obtain estimates of its prevalence within managed plots of switchgrass. Additional observations of the biology of Blastobasis infesting switchgrass were made, primarily from plots in Illinois.

\section{Methods}

While switchgrass is distributed throughout most of the United States, efforts to collect Blastobasis larvae focused on areas comprising the original tallgrass prairie. Southern states, including Texas, Oklahoma, Louisiana and Arkansas were surveyed during April 2009. Northern states of Illinois, Iowa, Nebraska, Wisconsin, Ohio, Michigan, South Dakota and North Dakota were visited during May and June 2009. Survey data for a single state, Ohio, came from a small roadside patch of switchgrass sampled en route to a seed production field in Michigan. In part, survey dates were selected in an attempt to visit fields when plants were $25-50 \mathrm{~cm}$ tall to make detection of dead, partially emerged leaves easier; unlike in regularly-spaced annual crops, the high density of tillers in switchgrass means that symptoms are more conspicuous when there is little or no height difference between infested and uninfested tillers.

At each survey location, a visual search was conducted for tillers with emerging leaves that were dead or dying. Because a late freeze or previous mechanical damage (e.g., from farm equipment or people walking though plots) may cause a similar appearance in emerging leaves, tillers were considered symptomatic only if a hole near the base of the stem also was visible (Fig. 1). For all locations where stem-boring larvae were present, a small number of larvae or pupae were collected to allow later examination of the specimens and storage as vouchers at the Illinois Natural History Survey insect collection. When time permitted, more intensive sampling was used to estimate the abundance of symptomatic tillers within a stand. To estimate the percentage of tillers lost to stem-borers, and Blastobasis in particular, five or ten points were arbitrarily selected within a plot; at each point, a subsample of 100 tillers was searched and each symptomatic tiller cut below soil level and placed into a clear plastic bag. Symptomatic tillers were later dissected by hand with tillers categorized as containing Blastobasis, other unidentified stem borers, or no stem-boring insects.

Additional observations were made using collections from field locations in Savoy, Illinois. Larvae were collected in May and June by removing symptomatic tillers from plots. Some of these larvae were confined with

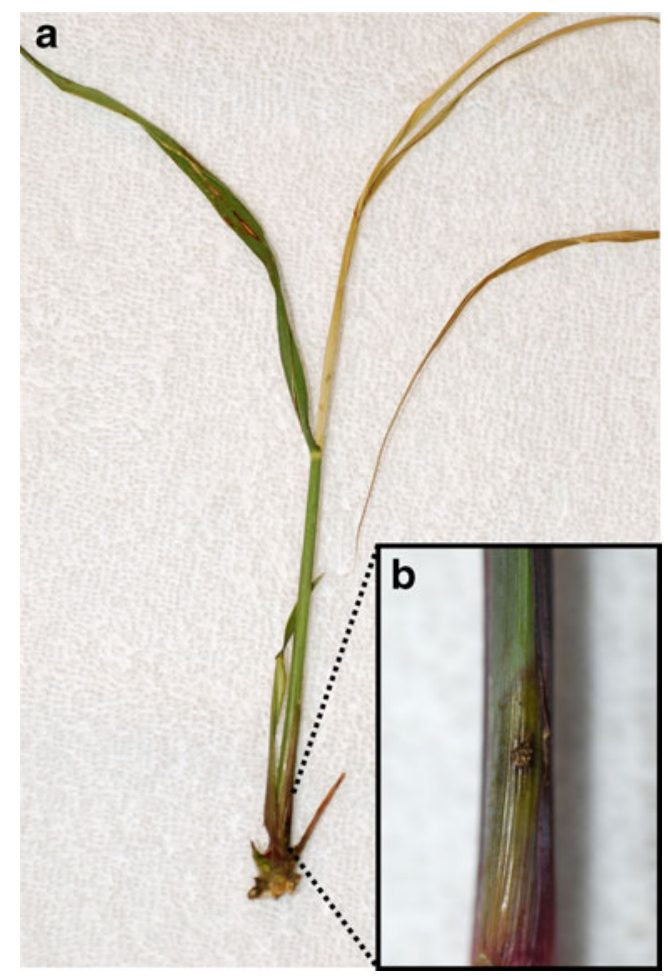

Fig. 1 Symptoms of Blastobasis repartella infestation. Switchgrass tiller a excised from field, and $\mathbf{b}$ with a detail of an entry wound 
Table 1 Switchgrass field sites surveyed for Blastobasis repartella, 2009

\begin{tabular}{|c|c|c|c|c|}
\hline Locations & Year established & Plot area (ha) & Cultivar & Sample date \\
\hline \multicolumn{5}{|c|}{ B. repartella not collected } \\
\hline Stephenville, $\mathrm{TX}^{\mathrm{a}}$ & 1995 & 0.08 & Alamo & April 6 \\
\hline Ardmore, OK & 2007 & 0.23 & lowland crosses & April 7 \\
\hline Homer, $\mathrm{LA}^{\mathrm{ab}}$ & 2001 & $<0.01$ & Alamo & April 8 \\
\hline Booneville, AR & 2002 & 1.01 & Alamo & April 8 \\
\hline \multicolumn{5}{|c|}{ B. repartella collected } \\
\hline Savoy, IL & 2004 & 0.19 & Cave-In-Rock & May 30 \\
\hline Ames, IA & 2004 & 0.01 & Cave-In-Rock & June 3 \\
\hline Mead, NE (1) & 2006 & 23.10 & Shawnee & June 4 \\
\hline Mead, NE (2) & 2002 & 0.40 & $\begin{array}{l}\text { Shawnee } \\
\text { Kanlow } \times \text { Summer } \\
\text { Summer } \times \text { Kanlow } \\
\text { Trailblazer }\end{array}$ & June 4 \\
\hline Arlington, $\mathrm{WI}^{\mathrm{c}}$ & 2005 & 0.20 & WS4U & June 16 \\
\hline Wauseon, $\mathrm{OH}^{\mathrm{d}}$ & unknown & $<0.01$ & none & June 23 \\
\hline East Lansing, MI & 1999,2000 & 0.41 & Southlow & June 24 \\
\hline Bristol, SD & 2001 & 6.1 & Trailblazer & June 30 \\
\hline Carrington, ND & 2006 & 0.02 & $\begin{array}{l}\text { Sunburst } \\
\text { Trailblazer }\end{array}$ & June 30 \\
\hline
\end{tabular}

${ }^{\text {a }}$ Plot minimally maintained.

Weedy with no cutting or burning of growth from previous

year

${ }^{\mathrm{b}}$ Planted as understory for loblolly pines, Pinus taeda L.

${ }^{\mathrm{c}}$ Source population detailed in Crop Sci 46:998-999

${ }^{\mathrm{d}}$ Sample taken from roadside patch if switchgrass

the eighth northern state sampled, examination of a small roadside patch of switchgrass produced one pupa from two symptomatic tillers (Table 1). Blastobasis larvae, pupae and adults (emerged from pupae) from these collections were examined and confirmed as $B$. repartella based on comparisons to museum specimens.

The degree of infestation by stem-borers was estimated to range from 1.0-7.2\%, with both the highest and lowest values occurring in plots near Mead, Nebraska. Among the five locations where the percentage of tillers lost to stemborers was assessed, survey locations varied considerably in size $(<1-23 \mathrm{ha})$ and age $(2-14$ years). Assuming about 600 tillers $/ \mathrm{m}^{2}$ [3], the data from five fields in four states suggest from 6-40 symptomatic tillers may be present in one square meter. Excluding Savoy, Illinois, the only location where another, unidentified stem-boring caterpillar (family Crambidae) was found, over $70 \%$ of the symptomatic tillers contained $B$. repartella (Table 2). In general, the symptomatic tillers that contained no larvae
Neither symptomatic tillers nor Blastobasis larvae were found at locations in Texas, Oklahoma, Louisiana and Arkansas. However, Blastobasis larvae were found in cultivated switchgrass at seven northern states; in Ohio,

Table 2 Estimated percentages of switchgrass tillers infested with Blastobasis repartella, 2009

\begin{tabular}{lcc}
\hline Location & Symptomatic tillers $(\% \pm \mathrm{SE})$ & Tillers with Blastobasis (\%) \\
\hline Savoy, IL & $3.2 \pm 0.8$ & $1.3 \pm 0.4^{\mathrm{a}}$ \\
Mead, NE (1) & $1.0 \pm 0.6$ & $0.8 \pm 0.5$ \\
Mead, NE (2) & $7.2 \pm 1.0$ & $5.0 \pm 1.3$ \\
Arlington, WI & $3.0 \pm 1.1$ & $2.4 \pm 1.0$ \\
Bristol, SD & $3.6 \pm 1.1$ & $2.3^{\mathrm{b}}$ \\
\hline
\end{tabular}

${ }^{a}$ Sample included another unidentified stem-boring caterpillar

${ }^{\mathrm{b}}$ Estimated from a single sample $(n=50)$ of symptomatic tillers in field 
contained frass (insect fecal material) indicative of insect feeding and appeared to be among the smallest tillers collected (height $<10 \mathrm{~cm}$ ).

From hundreds of symptomatic tillers collected from Savoy, Illinois during May and June, it appears no more than one $B$. repartella larva is found within a single tiller and the larval location within the stem seems to change. Just after symptoms appear larvae often are found above the hole near the base of the tiller; later in the season larvae are more likely to be found below soil level, as the larvae usually pupate within the most basal part of infested tillers. The larval entry hole near the base of the stem for $B$. repartella is generally within $3 \mathrm{~cm}$ of the soil surface, while entry holes for the unidentified stem-borer in Illinois are almost always found at a height greater than $3 \mathrm{~cm}$ above soil level. While larvae were sometimes successfully induced to burrow into small stems of 'Sunburst,' they seemed unable to enter more mature (i.e., thicker-stemmed) tillers in the same pot. The dissection of switchgrass plants caged with adult $B$. repartella revealed eggs deposited at the base of stems, but concealed beneath the desiccated sheath at the base of each tiller. Eggs were present on both currently growing switchgrass and stubble from previously cut tillers. The location of eggs and the subsequent life stages of $B$. repartella are shown in Fig. 2.

\section{Discussion}

Results suggest that in the north central United States, $B$. repartella may be ubiquitous in established stands of switchgrass, as it was found in all eight northern states in the survey. Though no locations were included for Indiana or Minnesota, B. repartella is almost certainly present in both states, which are bordered with three or four states where the stem-borers have been collected. However, fields in Texas, Oklahoma, Louisiana and Arkansas all failed to show evidence of stem-borers during one early-season visit (Table 1).

The four southern states are part of the native distribution for switchgrass, making it unclear whether the insect is not present, or if it was not detected for another reason. For example, a small proportion of infested tillers could go unnoticed because of less-thanideal timing. Plots may be infested but not show the dead heart symptom because larvae have not yet consumed enough tissue to kill emerging leaves. Also, based on observations in Wisconsin, it appears that plots with little regular management (i.e., weed control or harvest) may harbor fewer larvae. Since another Blastobasis species is known from Louisiana [13], additional sampling would be needed to have confidence in the absence of $B$. repartella in the United States.
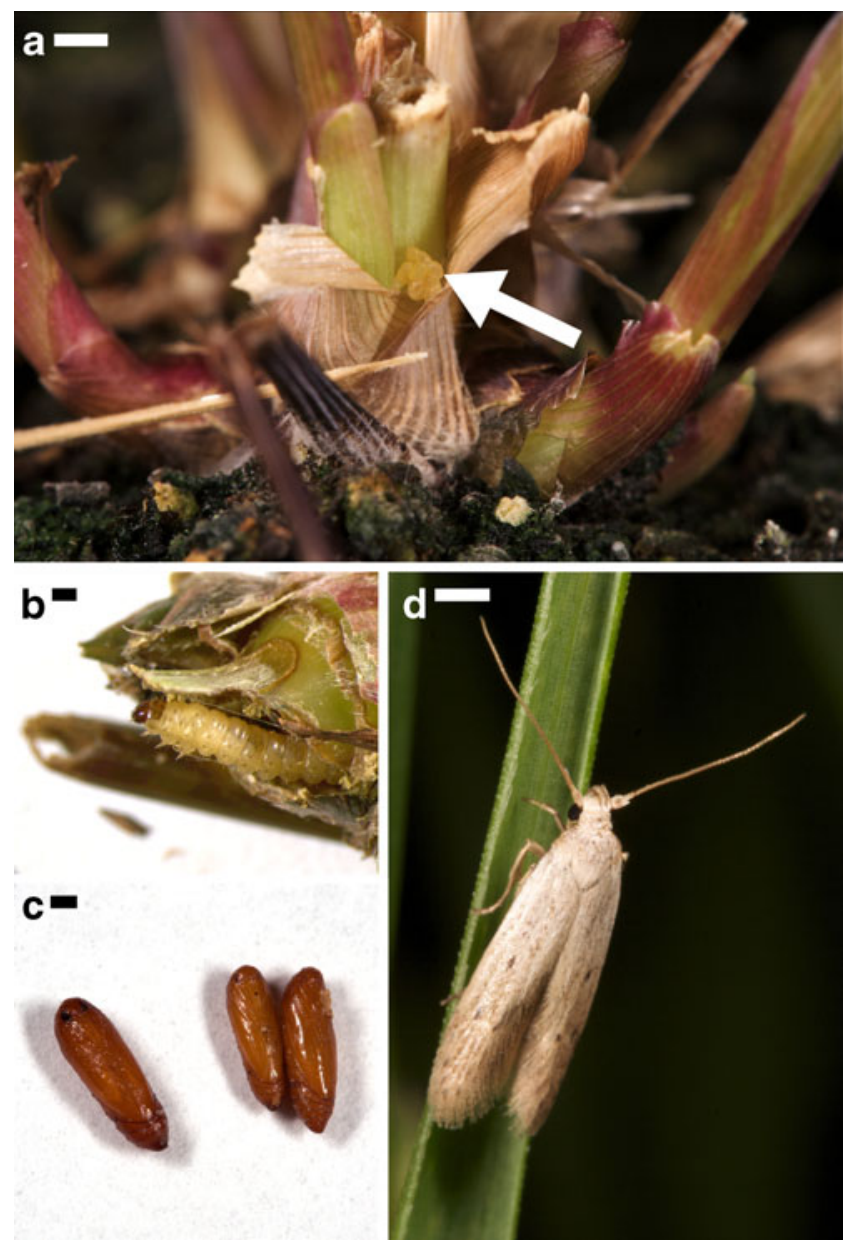

Fig. 2 Life stages of Blastobasis repartella. Photographs include a eggs, $\mathbf{b}$ larva, $\mathbf{c}$ pupae, and $\mathbf{d}$ adult. All plant parts are of switchgrass. Scale bars $($ each $\approx 1 \mathrm{~mm}$ ) are positioned next to figure letters

Based on more intensive sampling, the occurrence of symptomatic tillers of switchgrass was estimated to be modest $(<10 \%)$ across five locations in four states (Table 2$)$. Some tillers with dead heart and an entry hole did not contain caterpillars; such symptomatic tillers without larvae may have been once infested but abandoned, or larvae may have died from predation, parasitism or pathogens. However, because symptomatic tillers without $B$. repartella remain stunted, the proportion of tillers with dead heart and visible holes just above soil level (i.e., symptomatic tillers) may be a more accurate measure of activity by $B$. repartella where no other early-season stem borers are known.

Interestingly, the locations with the highest and lowest percentage of symptomatic tillers were located within $4 \mathrm{~km}$ of each other near Mead, Nebraska. Other than size, the primary difference between the locations is the number of years since plot establishment. If new switchgrass plantings are colonized by moths from nearby wild switchgrass or more distant fields, there may be a positive correlation between the age of fields and degree of 
infestation. However, since the percentage of tillers lost to $B$. repartella was accurately measured in only five locations, more research would be required to examine any relationship between stand age and degree of infestation.

Because the injury by B. repartella occurs early, it seems possible that switchgrass could compensate for the loss of some tillers. However, under a scenario where the area of switchgrass grown for bioenergy greatly expands, it is possible that stem-borer abundance could also increase and become problematic; control of other internal feeders is often a challenge because larvae are protected by feeding within the plant, requiring precisely timed insecticide applications [9]. Stem-borers of native grasses that deposit eggs on leaves can be controlled by burning [6], but the sheltered location of eggs and the presence of aboveaverage infestation in a location that was burned early in 2009 (Bristol, South Dakota; Table 2) suggest this may not be an effective technique to suppress $B$. repartella.

As a potential pest of switchgrass planted for biomass production, much of the desired biological information for $B$. repartella is not yet known. For example, based on the relatively late emergence of adults in Illinois (June into July) and an apparent inability of larvae to tunnel into mature switchgrass stems, the insect is presumed (but not known) to have one generation per year. Besides better understanding the life-history of the insect, there are also near-term needs to refine the geographic distribution of $B$. repartella, to quantify potential losses of switchgrass biomass, and to determine whether switchgrass may be bred for resistance to this and other stem-boring insects.

Acknowledgements Research funding was provided by the Energy Biosciences Institute. The authors wish to thank a number of people who assisted in locating and surveying field plots of switchgrass; Jerry Roitsch (Bristol, South Dakota), Jim Muir (Texas AgriLife Research), Twain Butler (The Samuel Roberts Noble Foundation), Mike Blazier (Lousiana State University Agricultural Center), Randy King (USDA-NRCS), Ken Moore (Iowa State University), Rob Mitchell (USDA-ARS), Mike Casler (USDA-ARS), John Leif (USDA-NRCS), and Yvonne Lawley (North Dakota State University).
Open Access This article is distributed under the terms of the Creative Commons Attribution Noncommercial License which permits any noncommercial use, distribution, and reproduction in any medium, provided the original author(s) and source are credited.

\section{References}

1. Adamski D (1999) Blastobasis graminea, new species (Lepidoptera: Gelechioidea: Coleophoridae: Blastobasinae), a stem borer of sugar cane in Colombia and Venezuela. Proc Entomol Soc Wash 101:164-174

2. Adamski D, Brown JW, Villanueva-Jimenez A (2000) First records of the sugarcane pest, Blastobasis graminea Adamski (Lepidoptera: Coleophoridae: Blastobasinae), from Mexico and Central America. Proc Entomol Soc Wash 104:812-813

3. Boe A, Beck DL (2008) Yield components of biomass in switchgrass. Crop Sci 48:1306-1311

4. Bouton J (2008) Improvement of switchgrass as a bioenergy crop. In: Vermerris W (ed) Genetic improvement of bioenergy crops, pp 295-308

5. Davis PM, Pedigo LP (1991) Injury profiles and yield responses of seedling corn attacked by stalk borer (Lepidoptera: Noctuidae). J Econ Entomol 84:294-299

6. Decker GC (1930) Corn-boring insects of Iowa with special reference to the stalk borer, Papaipema nebris (Gn.) and the fourlined borer, Luperina stipata (Morr.). Ph.D. Dissertation. Iowa State University, Ames. $174 \mathrm{pp}$

7. Dietz WG (1910) Revision of the Blastobasidae of North America. Trans Am Entomol Soc (Phila.) 36:1-72

8. Mitchell R, Vogel KP, Sarath R (2008) Managing and enhancing switchgrass as a bioenergy feedstock. Biofuels Bioprod Bioref 2:530-539

9. Nault BA, Kennedy GG (1996) Timing insecticide applications for managing European corn borer (Lepidoptera: Pyralidae) infestations in potato. Crop Prot 15:465-71

10. Nyoka B, Jeranyama P, Owens V, Boe A, Moechnig M (2007) Management guide for biomass feedstock production from switchgrass in the Northern Great Plains. Publication SGINC207, Brookings, SD: South Dakota State University

11. Parrish D, Fike J (2005) The biology and agronomy of switchgrass for biofuels. Crit Rev Plant Sci 24:423-459

12. Semere T, Slater FM (2007) Invertebrate populations in Miscanthus (Miscanthus x giganteus) and reed canary-grass (Phalaris arundinacea) fields. Biomass Bioenergy 31:30-39

13. White WH, Adamski D, Fine G, Richard EP (2005) Stemborers associated with smooth cordgrass, Spartina alterniflora (Poaceae), in a nursery habitat. Fla Entomol 88:390-394 